\title{
PENENTUAN STATUS PEMANFAATAN DAN SKENARIO PENGELOLAAN IKAN TONGKOL (Auxis rochei) YANG TERTANGKAP DI PERAIRAN KABUPATEN SIAU-TAGULANDANG-BIARO SULAWESI UTARA
}

\author{
John S. Kekenusa ${ }^{1)}$, Sendy B. Rondonuwu ${ }^{2)}$, Marline S. Paendong ${ }^{1)}$, Winsy Ch.D. Weku' ${ }^{1)}$ \\ 1)Jurusan Matematika FMIPA Universitas Samratulangi, Manado \\ ${ }^{2)}$ Jurusan Biologi FMIPA Universitas Samratulangi, Manado \\ e-mail: johnkekenusa@yahoo.com; rondonuwu64@yahoo.com; marline_paendong@yahoo.com; \\ winsyweku@gmail.com
}

\begin{abstract}
ABSTRAK
Ikan tongkol (Auxis rochei), perlu dikelola dengan baik karena walaupun sebagai sumberdaya alam terbarukan, namun dapat mengalami deplesi ataupun kepunahan. Salah satu pendekatan dalam pengelolaan sumberdaya ikan ialah dengan pemodelan. Analisis dilakukan bertujuan untuk mendapatkan model terbaik untuk model produksi surplus guna mengetahui tangkapan maksimum lestari (MSY), tingkat pemanfaatan, dan pengupayaan ikan tongkol. Data hasil tangkapan dan upaya tangkap ikan tongkol dikumpulkan dari Dinas Kelautan dan Perikanan Kabupaten Siau-Tagulandang-Biaro dan Dinas Kelautan dan Perikanan Provinsi Sulawesi Utara Sulawesi. Model Produksi Surplus terbaik, yang digunakan untuk menilai potensi ikan tongkol ialah model Schaefer. Upaya optimal ( $\left.\mathrm{E}_{\mathrm{MSY}}\right)$ sebesar 5436 trip per tahun. Hasil tangkapan optimal $\mathrm{C}_{\mathrm{MSY}}$ sebesar 1040,94 ton per tahun. Tingkat pemanfaatan untuk tahun 2013 ialah 103,80\%, dengan tingkat pengusahaan sebesar $110,56 \%$, yang menunjukkan terjadi tangkap-lebih (overfishing).
\end{abstract}

Kata Kunci : Ikan tongkol, Model Produksi Surplus,Tangkapan Maksimum Lestari, Siau-Tagulandang-Biaro

\section{DETERMINATION OF THE STATUS OF UTILIZATION AND MANAGEMENT SCENARIOS BONITO (Auxis rochei) CAUGHT IN THE SIAU-TAGULANDANG-BIARO REGENCY NORTH SULAWESI}

\begin{abstract}
Bonito (Auxis rochei), needs to be managed well as a renewable natural resources, but vunerable to depletion or extinction. One approach in fish resource management is by modeling. Analysis were carried out, aimed to get the best model for surplus production model, to assess the Maximum Sustainable Yield (MSY), and to get the bonito utilization and effort level. Data used for surplus production model were collected from bonito landings data provided by Marine and Fisheries Service (Dinas Kelautan dan Perikanan) of Siau-Tagulandang-Biaro Regency and North Sulawesi Province. The best Surplus Production Model that can be used to assess the bonito potential yield is the Schaefer model. The optimum effort biologically $\mathrm{E}_{\mathrm{MSY}}$ is 5,436 trips per year. The optimum yield biologically $\mathrm{C}_{\mathrm{MSY}}$ is $1,040.94$ tons per year. Utilization level for 2013 was $103.80 \%$, with effort level $110.56 \%$. The catch for 2013 had already above the MSY value, which shows an overfishing.
\end{abstract}

Keywords : Bonito, Surplus Production Model, Maximum Sustainable Yield, Siau-Tagulandang-Biaro

\section{PENDAHULUAN}

Ikan tongkol (Auxis rochei) tergolong sumberdaya perikanan pelagis penting dan merupakan salah satu komoditi ekspor nir- migas. Produksi ikan tongkol di Sulawesi Utara (termasuk Kabupaten Kepulauan SITARO = Siau-Tagulandang-Biaro) pada tahun 2011 mencapai sekitar 30.000 ton, 
dengan nilai sekitar 300 milyar rupiah (DKP Sulawesi Utara, 2012). Penelitian tentang ikan tongkol umumnya membahas tentang eksploitasi untuk meningkatkan produksi, belum banyak yang meneliti tentang status pemanfaatan (termasuk aspek kelestarian dan efisiensi) sumberdaya.

Penangkapan ikan tongkol di perairan SITARO telah berlangsung cukup lama, dengan intensitas yang padat. Data mengenai tingkat pemanfaatan suatu sumberdaya ikan sangat penting, karena akan menentukan apakah pemanfaatan sumberdaya tersebut kurang optimal, optimal, atau berlebih. Pemanfaatan sumberdaya ikan yang berlebihan akan mengancam kelestariannya. Dengan mengetahui tingkat pemanfaatan sumberdaya tongkol, diharapkan dapat dilakukan pengelolaan yang terencana dan lestari.

Model yang paling sederhana dalam dinamika populasi ikan ialah Model Produksi Surplus (MPS), dengan memperlakukan ikan sebagai biomassa tunggal yang tak dapat dibagi, yang tunduk pada aturan-aturan sederhana kenaikan dan penurunan biomassa. Model ini, pada umumnya digunakan dalam penilaian stok ikan hanya dengan menggunakan data hasil tangkapan dan upaya tangkap yang umumnya tersedia.

Penelitian ini bertujuan untuk mendapatkan MPS terbaik, serta mengetahui berapa besar hasil tangkapan maksimum lestari (Maximum Sustainable Yield = MSY), tingkat pemanfaatan, dan tingkat pengusahaan ikan tongkol di perairan SITARO.

\section{MODEL PRODUKSI SURPLUS}

Model yang paling sederhana dalam dinamika populasi ikan ialah model produksi surplus yang memperlakukan populasi ikan sebagai biomassa tunggal yang tidak dapat dibagi, yang tunduk pada aturan-aturan sederhana dari kenaikan dan penurunannya. Model produksi ini tergantung pada 4 macam besaran, yaitu : biomassa populasi pada suatu waktu tertentu $\mathrm{t}\left(\mathrm{B}_{\mathrm{t}}\right)$, tangkapan untuk suatu waktu tertentu $t\left(C_{t}\right)$, upaya tangkap pada waktu tertentu $t\left(E_{t}\right)$, dan laju pertumbuhan alami konstan (r) (Boer dan Aziz, 1995). Model ini pertama kali dikembangkan oleh Schaefer, yang bentuk awalnya sama dengan model pertumbuhan logistik.
Menurut Coppola dan Pascoe (1996), persamaan surplus produksi terdiri dari beberapa konstanta yang dipengaruhi oleh pertumbuhan alami, kemampuan alat tangkap, dan daya dukung lingkungan. Konstanta-konstanta tersebut diduga dengan menggunakan model-model penduga parameter biologi dari persamaan surplus produksi, yaitu model : Equilibrium Schaefer, Disequilibrium Schaefer, Schnute, dan Walter - Hilborn. Berdasarkan keempat model tersebut dipilih yang paling sesuai atau best fit dari pendugaan yang lain.

Menurut Sparre dan Venema (1999), rumus-rumus model produksi surplus hanya berlaku apabila parameter slope (b) bernilai negatif, yang berarti penambahan upaya tangkap akan menyebabkan penurunan hasil tangkapan per upaya tangkap. Apabila parameter $\mathrm{b}$ nilainya positip, maka tidak dapat dilakukan pendugaan besarnya stok maupun upaya optimum, tetapi hanya dapat disimpulkan bahwa penambahan upaya tangkap masih memungkinkan untuk meningkatkan hasil tangkapan.

Pendugaan upaya penangkapan optimum ( $\left.\mathbf{E}_{\text {opt }}\right)$ dan hasil tangkapan maksimum lestari ( $\left.\mathbf{C}_{\mathbf{M S Y}}\right)$ didekati dengan Model Produksi Surplus. Antara hasil tangkapan per satuan upaya (Catch Per Unit of Effort = CPUE) dan upaya tangkap (effort) dapat berupa hubungan linear maupun eksponensial (Gulland, 1983). Model Produksi Surplus terdiri dari 2 model dasar yaitu Model Schaefer (hubungan linear) dan Model Gompertz yang dikembangkan oleh Fox dengan bentuk hubungan eksponensial (Gulland, 1983).

\section{Model Schaefer}

Model Produksi Surplus pertama kali dikembangkan oleh Schaefer, yang bentuk awalnya sama dengan model pertumbuhan logistik. Model tersebut ialah sebagai berikut:

$$
\frac{d B_{t}}{d t}=\mathrm{G}\left(B_{t}\right)=\mathrm{rB}_{\mathrm{t}}\left(1-\frac{B_{t}}{K}\right)
$$

Persamaan ini belum memperhitungkan pengaruh penangkapan, sehingga Schaefer menuliskan kembali menjadi :

$$
\frac{d B_{t}}{d t}=\mathrm{rB}_{\mathrm{t}}\left(1-\frac{B_{t}}{K}\right)-\mathrm{C}_{\mathrm{t}}
$$

dengan $\mathrm{K}$ ialah daya dukung lingkungan perairan, dan $\mathrm{C}_{\mathrm{t}}$ ialah tangkapan yang dapat ditulis sebagai :

$$
\mathrm{C}_{\mathrm{t}}=\mathrm{q} \mathrm{E}_{\mathrm{t}} \mathrm{B}_{\mathrm{t}}
$$


dengan q sebagai koefisien ketertangkapan (catchability), dan $\mathrm{E}_{\mathrm{t}}$ menunjukkan upaya tangkap. Persamaan ini dapat ditulis menjadi

$$
\frac{C_{t}}{E_{t}}=\mathrm{q} \mathrm{B}_{\mathrm{t}}=\text { CPUE }
$$

Dari persamaan diferensial (2), tangkapan optimum dapat dihitung pada saat $\frac{d B_{t}}{d t}=0$ atau disebut juga penyelesaian pada titik keseimbangan (equilibrium), yang berbentuk :

$\mathrm{rB}_{\mathrm{t}}\left(1-\frac{B_{t}}{K}\right)-\mathrm{C}_{\mathrm{t}}=0, \quad$ atau

$\mathrm{C}_{\mathrm{t}}=\mathrm{rB}_{\mathrm{t}}\left(1-\frac{B_{t}}{K}\right)=\mathrm{q} \mathrm{E}_{\mathrm{t}} \mathrm{B}_{\mathrm{t}}$

Dari persamaan (3) dan (5) diperoleh nilai $\mathrm{B}_{\mathrm{t}}$ sebagai berikut :

$\mathrm{B}_{\mathrm{t}}=\mathrm{K}\left(1-\frac{q E_{t}}{r}\right)$

Sehingga persamaan (5) menjadi :

$\mathrm{C}_{\mathrm{t}}=\mathrm{qK} \mathrm{KE}_{\mathrm{t}}\left(1-\frac{q E_{t}}{r}=\mathrm{qK} \mathrm{E}_{\mathrm{t}}-\frac{q^{2} K}{r} \mathrm{E}_{\mathrm{t}}^{2}(7)\right.$

Persamaan (7) disederhanakan lagi oleh Schaefer menjadi :

$\frac{C_{t}}{E_{t}}=\mathrm{a}-\mathrm{b} \mathrm{E}_{\mathrm{t}}$, atau $\mathrm{C}_{\mathrm{t}}=\mathrm{a} \mathrm{E}_{\mathrm{t}}-\mathrm{bE} \mathrm{E}_{\mathrm{t}}^{2}$

sedangkan $\mathrm{a}=\mathrm{q} \mathrm{K}$ dan $\mathrm{b}=\frac{q^{2} K}{r}$.

Hubungan linear ini yang digunakan secara luas untuk menghitung $\mathrm{C}_{\mathrm{MSY}}$ melalui penentuan turunan pertama $C_{t}$ terhadap $E_{t}$ untuk mencari solusi optimal, baik untuk tangkapan maupun upaya tangkap. Turunan pertama $\mathrm{C}_{\mathrm{t}}$ terhadap $\mathrm{E}_{\mathrm{t}}$ adalah : $\frac{d C_{t}}{d E_{t}}=\mathrm{a}-$

$2 b E_{t}$, sehingga diperoleh dugaan $E_{\text {opt }}$ (upaya tangkap optimum) dan $\mathrm{C}_{\mathrm{MSY}}$ (tangkapan maksimum lestari) masing-masing :

$\mathrm{E}_{\mathrm{opt}}=\frac{a}{2 b}=\frac{r}{2 q}$

dengan memasukkan nilai $\mathrm{E}_{\text {opt }}$ pada persamaan (8), akan diperoleh $\mathrm{C}_{\mathrm{MSY}}$ sebagai berikut :

$\mathrm{C}_{\mathrm{MSY}}=\mathrm{aE}_{\mathrm{t}}-\mathrm{bE}_{\mathrm{t}}^{2}=\mathrm{a}\left(\frac{a}{2 b}\right)-\mathrm{b}\left(\frac{a}{2 b}\right)^{2}=\frac{a^{2}}{4 b}$

dengan mensubstitusi $\mathrm{a}=\mathrm{qK}$ dan $\mathrm{b}=\frac{q^{2} K}{r}$, akan diperoleh

$\mathrm{C}_{\mathrm{MSY}}=\frac{a^{2}}{4 b}=\frac{q^{2} K^{2}}{4 q^{2} K / r}=\frac{r K}{4}$

Nilai-nilai a dan $b$ diduga melalui pendekatan metode kuadrat terkecil yang umum digunakan untuk menduga koefisien persamaan regresi sederhana. Selanjutnya, dengan memasukkan nilai $\mathrm{E}_{\mathrm{opt}}$ pada persamaan (6) diperoleh biomassa optimum ( $\mathrm{B}_{\mathrm{MSY}}$ ) sebagai berikut :

$$
\begin{gathered}
\mathrm{B}_{\mathrm{MSY}}=\mathrm{K}-\frac{K q}{r} E_{o p t}=\mathrm{K}-\frac{K q}{r}\left(\frac{r}{2 q}\right) \\
=\mathrm{K}-\frac{K}{2}=\frac{K}{2}
\end{gathered}
$$

Nilai-nilai parameter $\mathrm{q}, \mathrm{K}$, dan $\mathrm{r}$ dapat dihitung dengan menggunakan algoritma Fox, seperti yang diacu dalam Sularso (2005), sebagai berikut :

$\mathrm{q}_{\mathrm{t}}=\ln \left[\left(\mid z U_{t}^{-1}+\frac{1}{b}\right) /\left(z U_{t+1}^{-1}+\frac{1}{b}\right) \mid\right] /(z)$

dimana $\mathrm{z}=-(\mathrm{a} / \mathrm{b}) / \mathrm{E}^{*}, \quad \mathrm{E}^{*}=\left(\mathrm{E}_{\mathrm{t}}+\mathrm{E}_{\mathrm{t}+1}\right) / 2$, $U_{t}=\frac{C_{t}}{E_{t}}$, dan nilai $\mathrm{q}$ adalah rata-rata geometrik dari nilai $\mathrm{q}_{\mathrm{t}}$. Dari nilai $\mathrm{a}, \mathrm{b}$, dan $\mathrm{q}$, selanjutnya dapat dihitung nilai $\mathrm{K}$ dan $\mathrm{r}$.

\section{Model Fox}

Model Fox (1970) memiliki beberapa karakteristik yang berbeda dari model Schaefer, yaitu pertumbuhan biomassa mengikuti model pertumbuhan Gompertz. Penurunan CPUE terhadap upaya tangkap (E) mengikuti pola eksponensial negatif.

$\mathrm{C}_{\mathrm{t}}=\mathrm{E}_{\mathrm{t}} \cdot \exp \left(\mathrm{a}-\mathrm{b} \mathrm{E}_{\mathrm{t}}\right)$

Upaya optimum diperoleh dengan menyamakan turunan pertama $C_{t}$ terhadap $E_{t}$ sama dengan nol :

$\mathrm{E}_{\mathrm{opt}}=\frac{1}{b}$

Hasil tangkapan maksimum lestari $\left(\mathrm{C}_{\mathrm{MSY}}\right)$ didapat dengan memasukkan nilai upaya optimum ke dalam persamaan (13), dan diperoleh :

$\mathrm{C}_{\text {MSY }}=\frac{1}{b} \mathrm{e}^{\mathrm{a}-1}$

\section{Model Schnute}

Schnute (1977), mengemukakan versi lain dari model produksi surplus yang bersifat dinamis serta deterministik. Metode Schnute dianggap sebagai modifikasi dari model Schaefer dalam bentuk diskret (Roff, 1983, yang diacu dalam Tinungki 2005).

$$
\ln \left(\frac{U_{t+1}}{U_{t}}\right)=\mathrm{r}-\frac{r}{q K}\left(\frac{U_{t}+U_{t+1}}{2}\right)-\mathrm{q}\left(\frac{E_{t}+E_{t+1}}{2}\right)
$$




$$
=\mathrm{a}-\mathrm{b}\left(\frac{U_{t}+U_{t+1}}{2}\right)-\mathrm{c}\left(\frac{E_{t}+E_{t+1}}{2}\right)
$$

dimana $\mathrm{a}=\mathrm{r}, \mathrm{b}=\frac{r}{q K}$, dan $\mathrm{c}=\mathrm{q}$, adalah penduga parameter koefisien regresi berganda.

\section{Model Walter - Hilborn}

Walter dan Hilborn (1976) yang diacu dalam Tinungki (2005), mengembangkan jenis lain dari model produksi surplus, yang dikenal sebagai model regresi. Model Walter - Hilborn ini, menggunakan persamaan diferensial sederhana, dengan persamaan sebagai berikut:

$$
\frac{U_{t+1}}{U_{t}}-1=\mathrm{r}-\frac{r}{K q} \mathrm{U}_{\mathrm{t}}-\mathrm{qE}_{\mathrm{t}}
$$$$
=\mathrm{a}-\mathrm{b} \mathrm{U}_{\mathrm{t}}-\mathrm{c} \mathrm{E}_{\mathrm{t}}
$$

dimana $\mathrm{a}=\mathrm{r}, \mathrm{b}=\frac{r}{K q}$, dan $\mathrm{c}=\mathrm{q}$, adalah

penduga parameter koefisien regresi berganda.

\section{Model Clarke Yoshimoto Pooley (CYP)}

Pendugaan parameter biologi untuk model produksi surplus dapat pula dilakukan melalui teknik pendugaan yang dikemukakan oleh Clarke, Yoshimoto, dan Pooley (Fauzi dan Anna 2005, Tinungki 2005). Parameterparameter yang diduga ialah $\mathrm{r}, \mathrm{K}$, dan $\mathrm{q}$, dengan model yang dinyatakan sebagai berikut :

$$
\ln \left(U_{t+1}\right)=\left(\frac{2 r}{2+r}\right) \ln (q K)+\frac{2-r}{2+r} \ln \left(U_{t}\right)-\frac{q}{2+r}\left(E_{t}+E_{t+1}\right)
$$

di mana : $\quad a^{\prime}=\frac{2 r}{2+r}, \quad a=a^{\prime} \ln (q K)$,

$b=\frac{2-r}{2+r}, \quad c=\frac{q}{2+r}$

dengan demikian persamaan (18) dapat ditulis dalam bentuk :

$$
\begin{aligned}
\ln \left(U_{t+1}\right) & =a^{\prime} \ln (q K)+b \ln \left(U_{t}\right)-c\left(E_{t}+E_{t+1}\right) \\
& =a+b \ln \left(U_{t}\right)-c\left(E_{t}+E_{t+1}\right)
\end{aligned}
$$

\section{METODE PENELITIAN Sumber Data}

Data yang dikumpulkan ialah data primer dan sekunder hasil tangkapan ikan tongkol di perairan Siau-Tagulandang-Biaro. Data produksi dan upaya tangkap dikumpul dari Dinas Kelautan dan Perikanan Kabupaten Siau-Tagulandang-Biaro dan Provinsi Sulawesi Utara selama tahun 2008 2013.

Data (variabel) yang digunakan untuk analisis model produksi surplus ialah data hasil tangkapan $\left(\mathrm{C}_{\mathrm{t}}\right)$ per tahun dan upaya tangkap $\left(\mathrm{E}_{\mathrm{t}}\right)$ per tahun, serta $\operatorname{CPUE}\left(\frac{C_{t}}{E_{t}}\right)$.

Data (variabel) utama yang digunakan untuk analisis model produksi surplus ialah sebagai berikut :

1. Hasil tangkapan $\left(\mathrm{C}_{\mathrm{t}}\right) \quad$ : berat ikan yang didaratkan (ton) pada tahun ke $\mathrm{t}$

2. Upaya tangkap $\left(E_{\mathfrak{t}}\right)$ : jumlah kapal motor penangkap ikan yang mendaratkan hasilnya di tempat pendaratan (trip) pada tahun ke $\mathrm{t}$

3. $\frac{C_{t}}{E_{t}}: \mathrm{C}_{\mathrm{t}}$ dibagi $\mathrm{E}_{\mathrm{t}}$ (ton/trip) pada tahun ke $\mathrm{t}$

\section{Metode Analisis Data}

Model penduga yang dianalisis dan dievaluasi ialah model : Schaefer, Fox, Schnute, Walter-Hilborn, dan Clarke Yoshimoto Pooley (CYP). Berdasarkan hasil evaluasi secara statistika sesuai (kesesuaian tanda, nilai $\mathrm{R}^{2}$, nilai validasi, dan signifikansi koefisien regresi model), akan diperoleh suatu model yang "terbaik" sebagai penduga. Dari model terbaik tersebut dihitung nilai $\mathrm{C}_{\mathrm{MSY}}$, upaya tangkap optimum ( $\mathrm{E}_{\mathrm{MSY}}$ ), tingkat pemanfaatan, dan tingkat pengusahaan sumberdaya perikanan tongkol.

\section{HASIL DAN PEMBAHASAN}

Hasil tangkapan perikanan tongkol di perairan SITARO dari tahun ke tahun relatif tetap. Data hasil tangkapan selang tahun 2008-2013, disajikan pada Tabel 1. 
Tabel 1. Jumlah hasil tangkapan, upaya tangkap, dan CPUE ikan tongkol di perairan SITARO tahun 2008-2013

\begin{tabular}{|c|c|c|c|}
\hline Tahun & $\begin{array}{c}\text { Tangkapan } \\
\text { (ton) }\end{array}$ & $\begin{array}{c}\text { Upaya } \\
\text { (trip) }\end{array}$ & $\begin{array}{c}\text { CPUE }=\frac{C_{t}}{E_{t}} \\
\text { (ton/trip }\end{array}$ \\
\hline 2008 & 945,2 & 7140 & 0,13238 \\
\hline 2009 & 900,3 & 7400 & 0,12166 \\
\hline 2010 & 950,2 & 7000 & 0,13574 \\
\hline 2011 & 990,4 & 6000 & 0,16507 \\
\hline 2012 & 1008,8 & 6100 & 0,16538 \\
\hline 2013 & 1080,5 & 6010 & 0,17978 \\
\hline $\begin{array}{c}\text { Rata- } \\
\text { rata }\end{array}$ & $\mathbf{9 7 9 , 2}$ & $\mathbf{6 6 0 8 , 3}$ & $\mathbf{0 , 1 5 0 0 0}$ \\
\hline
\end{tabular}

Sumber : Diolah dari data Dinas Kelautan dan Perikanan Kabupaten SITARO dan Provinsi Sulawesi Utara

Hasil analisis regresi untuk model produksi surplus disajikan pada Lampiran 1, yang diuraikan sebagai berikut :

\section{Model Schaefer}

Dari hasil analisis diperoleh persamaan regresi $\frac{C_{t}}{E_{t}}=\mathbf{0 , 3 8 3}-$ $\mathbf{0 , 0 0 0 0 3 5 2 3} \mathbf{E}_{\mathbf{t}}$, dengan nilai koefisien determinasi $\left(\mathrm{R}^{2}\right)=0,953$ dan tingkat signifikansi $\mathrm{p}<0,01$. Dengan demikian model produksi penduga hasil tangkapan untuk model Schaefer sesuai persamaan (8) ialah : $C_{t}=0,383 E_{t}-0,00003523 E_{t}^{2}$.

Model Fox

Dari hasil analisis regresi diperoleh persamaan regresi :

$\operatorname{Ln} \frac{C_{t}}{E_{t}}=\mathbf{- 0 , 3 3 5}-\mathbf{0 , 0 0 0 2 3 8} \mathrm{E}_{\mathbf{t}}$, dengan $\mathrm{R}^{2}=$ $0,982$ ( $\mathrm{p}<0,01)$. Penduga hasil tangkapan untuk model Fox sesuai persamaan (13) :

$C_{t}=E_{t} \cdot e^{(-0,335-0,000238 ~ E t)}$.

\section{Model Schnute}

Untuk metode Schnute sesuai persamaan (16), didapatkan persamaan regresi : $\operatorname{Ln}\left(\mathbf{U}_{t+1} / \mathbf{U}_{t}\right)=1,909-4,144$ $\left(\mathbf{U}_{t+1}+\mathbf{U}_{\mathrm{t}}\right) / \mathbf{2}-\mathbf{0 , 0 0 0 1 8 6}\left(\mathbf{E}_{t+1}+\mathbf{E}_{\mathrm{t}}\right) / \mathbf{2}$ dengan $\mathrm{R}^{2}=0,072$, dan semua koefisen regresi tidak ada yang signifikan $(\mathrm{p}>0,05)$.

\section{Model Walter - Hilborn}

Pada metode Walter-Hilborn dengan menggunakan persamaan (17) diperoleh persamaan regresi $\left(\mathbf{U}_{\mathbf{t}+1} / \mathbf{U}_{\mathfrak{t}}\right)-\mathbf{1}=\mathbf{2 , 3 4 5}-\mathbf{6 , 9 6 4}$ $\mathbf{U}_{\mathbf{t}} \mathbf{0 , 0 0 0 1 8 9} \mathbf{E}_{\boldsymbol{t}}$ dengan $R^{2}=0,036$, semua koefisien regresi tidak signifikan ( $p>0,05)$.

\section{Model Clarke Yoshimoto Pooley (CYP)}

Pada metode CYP diperoleh persamaan regresi, menurut persamaan (19) : $\operatorname{Ln}\left(\mathbf{U}_{\mathrm{t}+1}\right)=\mathbf{- 0 , 6 0 8}-\mathbf{0 , 7 7 8} \ln \left(\mathbf{U}_{\mathrm{t}}\right)-\mathbf{0 , 0 0 0 2 1 1}$ $\left(\mathbf{E}_{t}+\mathbf{E}_{t+1}\right)$ dengan $\mathrm{R}^{2}=0,962$, dan tidak semua koefisen regresi signifikan.

\section{PEMBAHASAN}

Hasil perhitungan validasi data untuk kelima model produksi surplus disajikan pada Lampiran 2, yang diringkas pada Tabel 2.

Tabel 2. Perhitungan validasi data untuk kelima model produksi

\begin{tabular}{|l|l|c|c|c|c|}
\hline & $\begin{array}{c}\text { Model } \\
\text { Schaefer }\end{array}$ & $\begin{array}{c}\text { Model } \\
\text { Fox }\end{array}$ & $\begin{array}{c}\text { Model } \\
\text { Schnute }\end{array}$ & $\begin{array}{c}\text { Model } \\
\text { Walter- } \\
\text { Hilborn }\end{array}$ & Model CYP \\
\hline $\begin{array}{l}\text { Kesesuaian } \\
\text { Tanda }\end{array}$ & Sesuai & $\begin{array}{c}\text { Tidak } \\
\text { Sesuai }\end{array}$ & Sesuai & $\begin{array}{c}\text { Tidak } \\
\text { Sesuai }\end{array}$ & $\begin{array}{c}\text { Tidak } \\
\text { Sesuai }\end{array}$ \\
\hline Nilai $\mathrm{R}^{2}$ & $\mathbf{0 , 9 5 3}$ & 0,964 & 0,072 & 0,036 & 0,962 \\
\hline Nilai Validasi & $\mathbf{0 , 0 2 0 1}$ & 0,0210 & 0,0399 & 0,0568 & 2,2955 \\
\hline $\begin{array}{l}\text { Signifikansi } \\
\begin{array}{l}\text { Koefisien } \\
\text { Regresi Individu }\end{array}\end{array}$ & Signifikan & $\begin{array}{c}\text { Tidak } \\
\text { Signifikan }\end{array}$ & $\begin{array}{c}\text { Tidak } \\
\text { Signifikan }\end{array}$ & $\begin{array}{c}\text { Tidak } \\
\text { Signifikan }\end{array}$ & Tidak Signifikan \\
\hline
\end{tabular}

Dari hasil perhitungan pada Tabel 2, terlihat bahwa yang paling sesuai ialah model Schaefer dengan nilai $\mathrm{R}^{2}$ sangat besar $\left(\mathrm{R}^{2}=\right.$ 0,953 ) dan validasi (nilai residual) paling kecil. Dari model Schaefer diperoleh nilai a $=0,383$ dan nilai $\mathrm{b}=0,00003523$, dengan persamaan (9) dan (10) dapat dihitung nilai upaya optimum $\left(\mathrm{E}_{\mathrm{opt}}\right)$ dan tangkapan maksimum lestari $\left(\mathrm{C}_{\mathrm{MSY}}\right)$ sebagai berikut :

$\mathrm{E}_{\mathrm{opt}}=\frac{a}{2 b}=\frac{0,383}{2(0,00003523)}=5435,708 \approx$

5436 trip/tahun. 
$\mathrm{C}_{\mathrm{MSY}}=\frac{a^{2}}{4 b}=\frac{0,383^{2}}{4(0,00003523)}=$ 1040,94 ton/tahun.

Ini berarti bahwa untuk menjaga kelestarian sumberdaya perikanan tongkol secara teknis dan biologis, dalam setahun jumlah unit penangkapan tidak boleh melebihi 5436 trip. Untuk menjaga kelestarian sumberdaya ikan tongkol di perairan Kabupaten Kepulauan SITARO, maksimum ikan tongkol yang dapat ditangkap sebesar 1040,94 ton per tahun.

Selanjutnya dari nilai $E_{\text {opt }}$ dan $C_{M S Y}$ dapat dihitung tingkat upaya penangkapan dan tingkat pemanfaatan ikan cakalang untuk tahun tertentu misalkan tahun 2013, sebagai berikut : Tingkat upaya tahun $2013=$ $\frac{E_{2013}}{E_{\text {opt }}} \times 100 \%=\frac{6010}{5436} \times 100 \%=110,56 \%$ Tingkat pemanfaatan tahun $2013=\frac{C_{2013}}{C_{M S Y}} \times$ $100=\frac{1080,5}{1040,94} \times 100 \%=103,80 \%$.

Dari hasil perhitungan, ternyata upaya tangkap ikan tongkol di perairan SITARO pada tahun 2013 sudah melebihi tingkat upaya maksimum lestari, demikian pula tingkat pemanfaatannya sudah melebihi 100 $\%$. Hal ini menunjukkan bahwa untuk tahun 2013 hasil tangkapan sudah melampaui batas tangkapan maksimum lestari atau terjadi overfishing (tangkap lebih).

Penelitian ini menjelaskan penggunaan beberapa kriteria statistika dalam memilih model produksi surplus terbaik. Dengan menerapkan beberapa kriteria statistika dalam memilih model produksi surplus, akan diperoleh hasil yang lebih baik. Para peneliti di bidang perikanan mendapatkan pedoman dalam menetapkan kriteria pemilihan model produksi surplus, sekaligus juga menghindari penerapan langsung satu model saja dalam menganalisis model produksi surplus di suatu perairan.

Karena adanya indikasi terjadi overfishing (tangkap lebih), disarankan agar pemerintah menerapkan peraturan mengenai pembatasan ukuran ikan tongkol yang akan ditangkap. Peraturan tersebut harus diawasi pelaksanaannya melalui sistem monitoring, controlling, dan surveillance (MCS) yang tegas. Selain itu, untuk mencegah tingkat pemanfaatan yang mengganggu kelestarian stok, perlu dilakukan pengaturan zonasi penangkapan melalui alokasi penggunaan rumpon yang menjadi daerah penangkapan ikan tongkol.

\section{KESIMPULAN DAN SARAN \\ Kesimpulan}

1. Model Produksi Surplus yang dapat digunakan untuk menelaah hasil tangkapan ikan tongkol di perairan SITARO ialah Model Schaefer, dengan persamaan : $\quad \mathbf{C}_{\mathbf{t}}=\mathbf{0 , 3 8 3} \mathbf{E}_{\mathrm{t}}$ $0,00003523 \mathrm{E}_{\mathrm{t}}^{2}$

2. Hasil tangkapan maksimum lestari ikan tongkol $\mathrm{C}_{\mathrm{MSY}}$ sebesar 1040,94 ton per tahun, diperoleh pada tingkat upaya tangkap E MSY 5436 trip. Untuk tahun 2013 besarnya tingkat pemanfaatan sebesar $103,80 \%$ dan ini tergolong overfishing (tangkap-lebih), dengan tingkat pengupayaan sebesar $110,56 \%$ juga sudah melampaui batas nilai optimum.

\section{Saran}

1. Dalam menerapkan model produksi surplus di suatu perairan, tidak hanya langsung menggunakan satu model tertentu saja, tetapi hendaknya menggunakan beberapa model yang dipilih berdasarkan kriteria statistika. Kriteria tersebut menyangkut antara lain : kesesuaian tanda koefisien model, nilai koefisien determinasi $\left(\mathrm{R}^{2}\right)$, nilai validasi, dan signifikansi koefisien regresi model.

2. Karena ada indikasi terjadi overfishing (tangkap lebih) dan besarnya intensitas upaya penangkapan tongkol di perairan SITARO, disarankan secepatnya dilakukan pengawasan oleh pihak berkompeten untuk menangani masalah ini. Terutama melakukan efisiensi terhadap upaya tangkap.

3. Perlu adanya perbaikan sistem penyajian dan pengumpulan data perikanan yang dilakukan pemerintah, agar tersedia data yang sesuai untuk kebutuhan analisis pengelolaan sumberdaya. Sebagai contoh, untuk data upaya tangkap (effort) tidak hanya dicatat nilai nominalnya (jumlah kapal, jumlah alat, dan lain-lain), akan tetapi yang lebih penting lagi ialah nilai efektifnya. Misalnya jumlah hari-kapal (boat-day) yaitu jumlah kapal dikali jumlah hari operasi. Data seperti ini lebih 
dapat menggambarkan efektifitas upaya tangkap, dibanding dengan hanya jumlah kapal atau jumlah alat tangkap yang digunakan yang belum tentu semuanya efektif.

\section{DAFTAR PUSTAKA}

Boer, M., dan K.A. Azis. 1995. Prinsipprinsip Dasar Pengelolaan Sumberdaya Perikanan Melalui Pendekatan BioEkonomi. Jurnal Ilmu-ilmu Perairan dan Perikanan III(2):109-119.

Coppola G., and S. Pascoe. 1996. A Surplus Production Model with a non-linear Catch-Effort Relationship. (Research Paper 105) Center for the Economics and Managemant of Aquatic Resources University of Portsmouth.

[DKP] Dinas Kelautan dan Perikanan Provinsi Sulawesi Utara. 2012. Statistik Perikanan Tangkap Provinsi Sulawesi Utara Tahun 2011.

Fauzi, A., dan S. Anna. 2005. Pemodelan Sumberdaya Perikanan dan Kelautan untuk Analisis Kebijakan. PT. Gramedia Pustaka Utama, Jakarta.

Fox, W.W. 1970. An Exponential Surplus Yield Model for Optimazing Exploited Fish Population. Trans. Am. Fish Soc. 99(1):80-88.

Gulland, J.A. 1983. Fishing and Stock of Fish at Iceland. Mui.`Agric. Fish Food, Invest. (Ser.2) 23(4): $52-70$.

Kekenusa, J.S. 2006. Pemodelan Hasil Tangkapan dan Evaluasi Model Produksi Surplus Ikan Cakalang yang Tertangkap di Perairan Sekitar Bitung Provinsi Sulawesi Utara. Disertasi (Tidak Dipublikasikan). Program Pascasarjana Universitas Airlangga. Surabaya. 140 hal.

Kekenusa, J.S. 2007. Analisis Bio-ekonomi Ikan Cakalang yang Tertangkap di Perairan Sekitar Bitung Provinsi Sulawesi Utara. Pacific Journal Vol.2 No.1 :71-76.

Kekenusa, J.S., V.N.R. Watung, Dj. Hatidja, dan A.J. Rindengan. 2008. Penentuan Status Pemanfaatan dan Skenario Pengelolaan Ikan Cakalang (Katsuwonus pelamis) yang Tertangkap di Perairan Sulawesi Utara. Laporan Penelitian Hibah Bersaing.
Kekenusa, J.S., V.N.R. Watung, dan Dj. Hatidja. 2009. Penentuan Status Pemanfaatan dan Skenario Pengelolaan Ikan Cakalang (Katsuwonus pelamis) yang Tertangkap di Perairan SangiheTalaud. Laporan Kegiatan Penelitian Strategis Nasional Tahun 2009.

Meyer, W.J. $1987 . \quad$ Concepts of Mathematical Modelling. McGrawHill Inc. New York. 439p.

Monintja, D. R., dan R. Yusfiandayani. 1999. Teknologi Penangkapan Ikan Cakalang dan Tuna. Laboratorium Teknologi Penangkapan Ikan, FPIKIPB. Bogor. 27 hal.

Monintja, D. R., dan R. Yusfiandayani. 2001. Pemanfaatan Sumberdaya Pesisir Dalam Bidang Perikanan Tangkap. Prosiding Pelatihan Pengelolaan Wilayah Pesisir Terpadu. IPB, Bogor.

Schnute, J. 1977. Improved Estimates from the Schaefer Production Models : Theoretical Considerations : J. Fish. Res. Board Can., 34:583-663.

Sparre , P. and S.C. Venema. 1999. Introduksi Pengkajian Stok Ikan Tropis. Buku 1 Manual. (Terjemahan J. Widodo. I.G.S. Merta, S. Nurhakim, dan M. Badrudin). Pusat Penelitian dan Pengembangan Perikanan, Badan Penelitian dan Pengembangan Pertanian (Kerjasama dengan Organisasi Pangan dan Pertanian Perserikatan Bangsa-bangsa). Jakarta. 438 hal.

Sularso, A. 2005. Alternatif Pengelolaan Perikanan Udang di Laut Arafura. Disertasi (Tidak Dipublikasikan). Sekolah Pascasarjana Institut Pertanian Bogor. Bogor. 130 hal.

Tinungki, G. M. 2005. Evaluasi Model Produksi Surplus dalam Menduga Hasil Tangkapan Maksimum Lestari untuk Menunjang Pengelolaan Perikanan Lemuru Di Selat Bali. Disertasi (Tidak Dipublikasikan). Sekolah Pascasarjana Institut Pertanian Bogor. Bogor. 207 hal.

Widodo, J. 1987. Modified Surplus Production Methods of Gulland (1961), and Schnute (1977). A Serial Seminars Published by Oceana XII(2):119-130.

Zar, J.H. 1984. Biostatistical Analysis. Prentice-Hall, New Jersey. 

Lampiran 1. Hasil analisis regresi Model Produksi Surplus

1. Model Schaefer

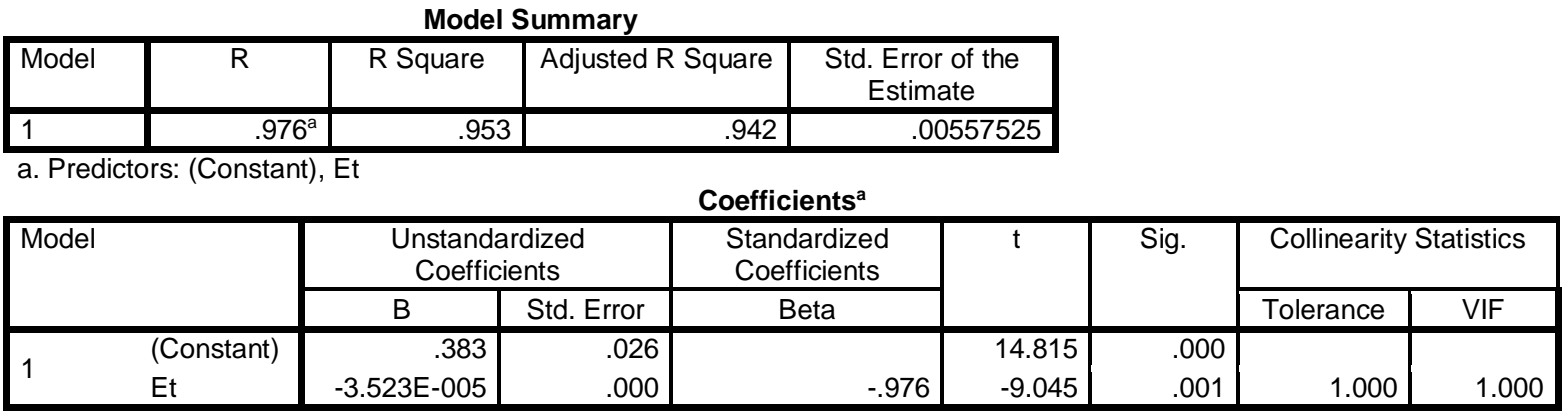

a. Dependent Variable: Ut

\section{Model Fox}

\begin{tabular}{|l|r|r|r|c|}
\hline Model & $R$ & $R$ Square & $\begin{array}{c}\text { Adjusted R } \\
\text { Square }\end{array}$ & $\begin{array}{c}\text { Std. Error of the } \\
\text { Estimate }\end{array}$ \\
\hline 1 & $.982^{\mathrm{a}}$ & .964 & .955 & .0329570184451 \\
\hline
\end{tabular}

\begin{tabular}{|c|c|c|c|c|c|c|c|}
\hline \multirow[t]{2}{*}{ Model } & \multicolumn{2}{|c|}{$\begin{array}{l}\text { Unstandardized } \\
\text { Coefficients }\end{array}$} & \multirow{2}{*}{$\begin{array}{c}\begin{array}{c}\text { Standardized } \\
\text { Coefficients }\end{array} \\
\text { Beta }\end{array}$} & \multirow[t]{2}{*}{$\mathrm{t}$} & \multirow[t]{2}{*}{ Sig. } & \multicolumn{2}{|c|}{ Collinearity Statistics } \\
\hline & $B$ & Std. Error & & & & Tolerance & VIF \\
\hline $\begin{array}{ll}1 & \text { (Constant) } \\
\mathrm{Et}\end{array}$ & $\begin{array}{r}-.335 \\
.000\end{array}$ & $\begin{array}{l}.153 \\
.000\end{array}$ & -.982 & $\begin{array}{r}-2.193 \\
-10.333\end{array}$ & $\begin{array}{l}.093 \\
.000\end{array}$ & 1.000 & 1.000 \\
\hline
\end{tabular}

\section{Model Schnute}

\begin{tabular}{|l|r|r|r|c|}
\hline Model & $\mathrm{R}$ & $\mathrm{R}$ Square & \multicolumn{1}{|c|}{ Adjusted R Square } & $\begin{array}{c}\text { Std. Error of the } \\
\text { Estimate }\end{array}$ \\
\hline 1 & $.268^{\mathrm{a}}$ & .072 & -.856 & .14551782 \\
\hline
\end{tabular}

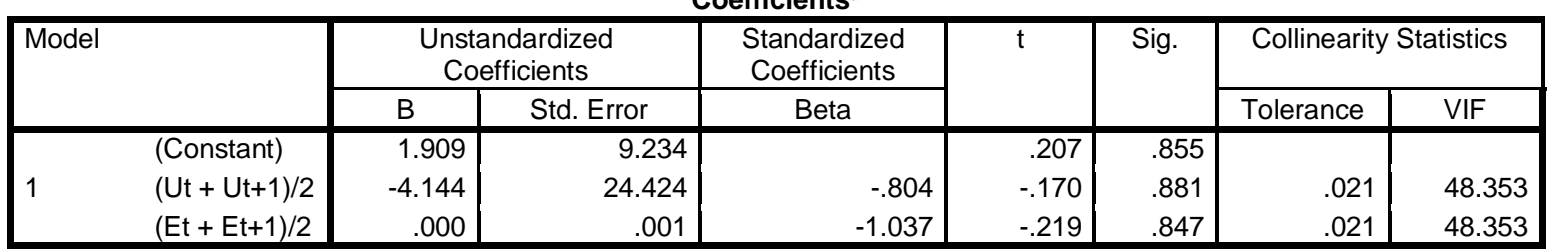

a. Dependent Variable: Ln (Ut+1/Ut)

\section{Model Walter - Hilborn}

\section{Model Summary}

\begin{tabular}{|l|r|r|r|c|}
\hline Model & \multicolumn{1}{|c|}{$\mathrm{R}$} & R Square & Adjusted R Square & $\begin{array}{c}\text { Std. Error of the } \\
\text { Estimate }\end{array}$ \\
\hline 1 & $.189^{\mathrm{a}}$ & .036 & -.929 & .15702548 \\
\hline
\end{tabular}

\section{a. Predictors: (Constant), Et, Ut $\quad$ Coefficients $^{\mathrm{a}}$}

\begin{tabular}{|c|c|c|c|c|c|c|c|c|}
\hline \multirow{2}{*}{\multicolumn{2}{|c|}{ Model }} & \multicolumn{2}{|c|}{$\begin{array}{c}\text { Unstandardized } \\
\text { Coefficients }\end{array}$} & $\begin{array}{c}\text { Standardized } \\
\text { Coefficients }\end{array}$ & \multirow[t]{2}{*}{$\mathrm{t}$} & \multirow[t]{2}{*}{ Sig. } & \multicolumn{2}{|c|}{ Collinearity Statistics } \\
\hline & & $B$ & Std. Error & Beta & & & Tolerance & VIF \\
\hline \multirow{3}{*}{1} & (Constant) & 2.345 & 18.306 & & .128 & .910 & & \\
\hline & Ut & -6.964 & 51.500 & -1.233 & -.135 & .905 & .006 & 172.422 \\
\hline & $\mathrm{Et}$ & .000 & .002 & -1.066 & -.117 & .918 & .006 & 172.422 \\
\hline
\end{tabular}

a. Dependent Variable: $(\mathrm{Ut}+1 / \mathrm{Ut})-1$ 


\section{Model CYP}

Model Summary

\begin{tabular}{|l|r|r|r|c|}
\hline Model & \multicolumn{1}{|c|}{$\mathrm{R}$} & $\mathrm{R}$ Square & Adjusted R Square & $\begin{array}{c}\text { Std. Error of the } \\
\text { Estimate }\end{array}$ \\
\hline 1 & $.981^{\mathrm{a}}$ & .962 & .925 & .04439342 \\
\hline
\end{tabular}

\begin{tabular}{|c|c|c|c|c|c|c|c|c|}
\hline \multirow{2}{*}{\multicolumn{2}{|c|}{ Model }} & \multicolumn{2}{|c|}{$\begin{array}{l}\text { Unstandardized } \\
\text { Coefficients }\end{array}$} & \multirow{2}{*}{$\begin{array}{c}\begin{array}{c}\text { Standardized } \\
\text { Coefficients }\end{array} \\
\text { Beta } \\
\end{array}$} & \multirow[t]{2}{*}{$\mathrm{t}$} & \multirow[t]{2}{*}{ Sig. } & \multicolumn{2}{|c|}{ Collinearity Statistics } \\
\hline & & $B$ & Std. Error & & & & Tolerance & VIF \\
\hline \multirow{3}{*}{1} & (Constant) & -.608 & .328 & & -1.854 & .205 & & \\
\hline & Ln Ut & -.778 & .400 & -.666 & -1.947 & .191 & .161 & 6.201 \\
\hline & $E t+E t+1$ & .000 & .000 & -1.554 & -4.542 & .045 & .161 & 6.201 \\
\hline
\end{tabular}

Lampiran 2. Validasi model produksi surplus

\begin{tabular}{|c|c|c|c|l|l|l|l|}
\hline \multirow{2}{*}{ Tahun } & \multirow{2}{*}{$\begin{array}{c}\mathbf{C}_{\mathbf{t}} \\
\text { (ton) }\end{array}$} & \multirow{2}{*}{$\begin{array}{c}\mathrm{E}_{\mathrm{t}} \\
\text { (trip) }\end{array}$} & \multicolumn{5}{|c|}{ Validasi : Abs $\left(\frac{C_{t}-\hat{C}_{t}}{C_{t}}\right)$} \\
\cline { 4 - 8 } & & & Schaefer & Fox & Schnute & $\begin{array}{c}\text { Walter- } \\
\text { Hilborn }\end{array}$ & CYP \\
\hline 2008 & 945,2 & 7140 & 0,0069 & 0,0122 & 0,0530 & 0,0872 & 2,6991 \\
\hline 2009 & 900,3 & 7400 & 0,0052 & 0,0103 & 0,0495 & 0,1253 & 3,1288 \\
\hline 2010 & 950,2 & 7000 & 0,0047 & 0,0039 & 0,0733 & 0,0881 & 3,5212 \\
\hline 2011 & 990,4 & 6000 & 0,0397 & 0,0397 & 0,0392 & 0,0584 & 1,4598 \\
\hline 2012 & 1008,8 & 6100 & 0,0165 & 0,0128 & 0,1259 & 0,0400 & 1,5364 \\
\hline 2013 & 1080,5 & 6010 & 0,0474 & 0,0474 & 0,0582 & 0,0295 & 1,4278 \\
\hline Rataan & 979,23 & 6608,3 & $\mathbf{0 , 0 2 0 1}$ & 0,0210 & 0,0399 & 0,0568 & 2,2955 \\
\hline
\end{tabular}

1. Model Schaefer : $\hat{C}_{t}=0,383 E_{t}-0,00003523 E_{t}^{2}$

2. Model Fox : $\hat{C}_{t}=E_{t} \cdot e^{\left(-0,335-0,000238 E_{t}\right)}$

3. Model Schnute :

$$
\begin{aligned}
& \quad \hat{Y}=a-b X_{1}-c X_{2}=1,909-4,144 X_{1}-0,000186 X_{2} \\
& \mathrm{r}=\mathrm{a}=1,909 \quad \mathrm{q}=\mathrm{c}=0,000186 \quad \mathrm{~b}=\frac{r}{K q}=4,144 \\
& \mathrm{~K}=\frac{r}{b q}=\frac{1,999}{(4,144)(0,000186)}=2476,699 \\
& \hat{C}_{t}=K q E_{t}-\frac{K q^{2}}{r} E_{t}^{2}=0,4607 \mathrm{E}_{\mathrm{t}}-0,000045 \mathrm{E}_{\mathrm{t}}^{2}
\end{aligned}
$$

4. Model Walter-Hilborn : $\hat{Y}=a-b X_{1}-c X_{2}=2,345-6,964 X_{1}-0,000189 X_{2}$

$$
\begin{aligned}
\mathrm{r} & =\mathrm{a}=2,345 \quad \mathrm{q}=\mathrm{c}=0,000189 \quad \mathrm{~b}=\frac{r}{K q}=6,964 \\
\mathrm{~K} & =\frac{r}{b q}=\frac{2,345}{(6,964)(0,000189)}=1781,649 \\
\hat{C}_{t} & =K q E_{t}-\frac{K q^{2}}{r} E_{t}^{2}=0,3367 \mathrm{E}_{\mathrm{t}}-0,000027 \mathrm{E}_{\mathrm{t}}^{2}
\end{aligned}
$$


5. Model CYP : $\hat{Y}=a+b X_{1}-c X_{2}=-0,608-0,778 X_{1}-0,000211 X_{2}$

$$
\begin{aligned}
& r=\frac{2(1-b)}{1+b}=\frac{2(1+0,778)}{1-0,778}=16,018 \quad q=-c(2-r)=-0,000211(2-16,018)=0,00296 \\
& Q=\frac{a(2+r)}{2 r}=\frac{-0,608(2+16,018)}{2(16,018)}=-0,3419 \\
& K=\frac{e^{Q}}{q}=\frac{e^{-0,3419}}{0,00296}=240,0065 \\
& \hat{C}_{t}=K q E_{t}-\frac{K q^{2}}{r} E_{t}^{2}=0,7104 \mathrm{E}_{\mathrm{t}}-0,000131 \mathrm{E}_{\mathrm{t}}^{2}
\end{aligned}
$$

